\title{
Base Flow Index of Way Seputih River at Buyut Udik
}

\author{
A Yusuf ${ }^{1}$, D I Kusumastuti ${ }^{2 *}$, and E P Wahono ${ }^{2}$ \\ ${ }^{1}$ Department of Housing and Water Resources Management Lampung Province, Jl. Gatot Subroto No.50, Garuntang, \\ Bandar Lampung, Indoneisa \\ ${ }^{2}$ Department of Civil Engineering, Faculty of Engineering, Universitas Lampung, Jl. Prof. Soemantri Brojonegoro No. 1, \\ Bandar Lampung, 35145 Indonesia
}

*Email: kusumast@gmail.com

\author{
Article Information \\ Received: \\ 16 October 2019 \\ Received in revised form: \\ 28 November 2019 \\ Accepted: \\ 15 December 2019 \\ Volume 1, Issue 2, December 2019 \\ pp. $74-77$ \\ OUniversitas Lampung \\ http://dx.doi.org/10.23960/jesr.v1i2.27
}

\begin{abstract}
One of river flow components considered in watershed management is baseflow, the main contributor to the river flow during dry season. Ratio between baseflow to total flow is called Base Flow Index (BFI). In fact, BFI can be used as an indicator how good the catchment hydrology is. The purpose of this study is to analyze BFI of Way Seputih river at Buyut Udik Hydrometry Station. The method includes Recursive Digital Filter (RDF) method, which utilizes constant recession of hydrographs in displaying the ratio of baseflow from continuous discharge during periods when there is no direct runoff. Daily discharge data from Way Seputih river at Buyut Udik recorded from 1973 to 2006 is used. The result shows that yearly BFI values range from 0.142 to 0.487 and there is a decrease trend of yearly BFI over time. This result is confirmed by yearly average discharges which tend to decrease over time. These are affected by land cover degradation in Way Seputih catchment and this should be a concern for authorities to improve land and water conservation in Way Seputih catchment so that river flow could be maintained throughout the year.

Keywords: base flow index, baseflow, dry season
\end{abstract}

\section{INTRODUCTION}

$\mathrm{T}$ HE overall catchment area of Way Seputih is $7492.99 \mathrm{~km}^{2}$ with $245 \mathrm{~km}$ river length passing six regencies in Lampung Province. Sixty-one percent of the total catchment is located in Central Lampung Regency, with very large catchment area and the length of the river as evidenced from upstream in the Pubian and downstream areas to the Java Sea, the Way Seputih has an important function for the people of Central Lampung, Metro to East Lampung. Considering that the largest rice producing area in the Lampung Province is in the Central Lampung Regency, it is very important to maintain the availability of Way Seputih river discharge especially during the dry season.

One of the problems in Way Seputih catchment is degradation of land cover, especially decreasing area of dry land forest as well as dry land agriculture which may result in increasing runoff coefficient. On the other hand, land cover impacts the capability of soil to infiltrate water from rainfall. In the water may flow as lateral flow to the river and it is known as baseflow. One of river components used in watershed management is base flow as it was main contributor in the river discharge during the dry season. All aspects which need river discharge throughout the year will take into account baseflow analysis during design until operation of the projects.

There are several methods which can be used to analyze baseflow including isotope tracer analysis which consider water in the river consists of old and new water. New water is part of river discharge composed of mostly surface runoff (direct runoff or quick flow), while old water composed of baseflow. This method may give an accurate result to determine baseflow contribution to the river. However, this method is not suitable for a tropical region, such as Indonesia. Other methods used in estimating the availability of baseflow are graphical method and filter method such as Recursive Digital Filter. These two methods are used to analyze the separation of base flow from total flow using discharge data.

Some of the methods used in Recursive Digital Filter include Lyne \& Holick algorithm, Chapman 
algorithm, EWMA (Exponentially Weighted Moving Average) algorithm, Nathan and McMohan, Hughes $\mathrm{S} \& \mathrm{~W}$ and Eckhardt [1]. Previous works on BFI includes which compared some RDF methods by Chapman-Maxwell and Eckhardt against tracer methods [2]. Also, utilized two parameter Eckhardt RDF method to estimate the portion of soil water and groundwater on streamflow [3]. Other research used Lynn-Holick RDF method to show the change of spatial and temporal patterns of streamflow [4].

This study aims to analyze Base Flow Index (BFI) of Way Seputih River at Buyut Udik using the RDF method. In particular, the RDF method applied in this study is Lyne \& Holick algorithm. Base Flow Index for each year is calculated and the trend is analysed. The result is confronted against the trend of average yearly discharges and maximum yearly discharges. Land cover analysis also need to be conducted to see the correlation between Baseflow Index, yearly discharges and land cover in Way Seputih catchment.

\section{Materials AND MethodS}

The research was conducted in Way Seputih River which is geographically located in Central Lampung Regency, Metro City and East Lampung Regency, Lampung Province, Indonesia. Data used in this study is daily discharge data recorded from Way Seputih river at Hydrometry Station Buyut Udik (denoted as PDA 137). Using Buyut Udik as an outlet in this study, the catchment area is $1560.25 \mathrm{~km}^{2}$ which is about $20 \%$ of the whole catchment. Map of study area is presented in Figure 1. Discharge data used in this study is daily data, with data period is from 1973 to 2006. It was found that there is some missing data, and it was decided to omit the particular year if more than half year data is missing.

Daily discharge data is then analysed for baseflow separation using Recursive Digital Filter (RDF) method. The algorithm used is BFLOW (Lyne \& Holick algorithm) using the equations (1) and (2).

$$
q f_{(i)}=\alpha q f_{(i-1)}+\left(q_{(i)}-q_{(i-1)}\right) \frac{1+\alpha}{2}
$$

Where:

$\mathrm{q} f_{(i)} \quad$ : quickflow value on day- $i\left(\mathrm{~m}^{3} / \mathrm{s}\right)$

$\mathrm{q} f_{(i-I)}:$ quickflow value on the previous day $\left(\mathrm{m}^{3} / \mathrm{s}\right)$

$\mathrm{q}_{(i)} \quad$ : discharge value on day- $i\left(\mathrm{~m}^{3} / \mathrm{s}\right)$

$\mathrm{q}_{(i-1)}$ : discharge value on the previous day $\left(\mathrm{m}^{3} / \mathrm{s}\right)$

$\alpha \quad$ : parameter filter [5]

Also, base flow value obtained from eq. (2) below:

$$
q b=q-q f
$$

q : total discharge $\left(\mathrm{m}^{3} / \mathrm{s}\right)$

qf : quickflow value $\left(\mathrm{m}^{3} / \mathrm{s}\right)$

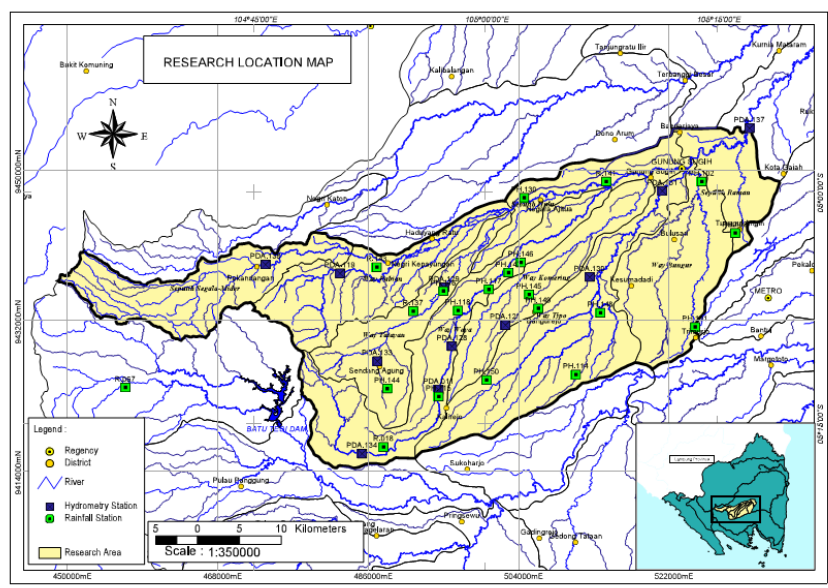

Figure 1. Study area of Way Seputih catchment

\section{RESULTS AND DISCUSSIONS}

Some results on baseflow separation using RDF Lyne \& Holick method is shown in Figure 2. The dash line is recorded discharge (total discharge) and the solid line is estimated baseflow using Lyne \& Holick method. BFI values for 1973 and 1999 are 0.487 and 0.230 respectively. It means that the contributions of baseflow to total discharge in 1973 and 1999 are $48.7 \%$ and $23 \%$ respectively. It is shown that there is a significant decrease of BFI values from 1973 to 1999.
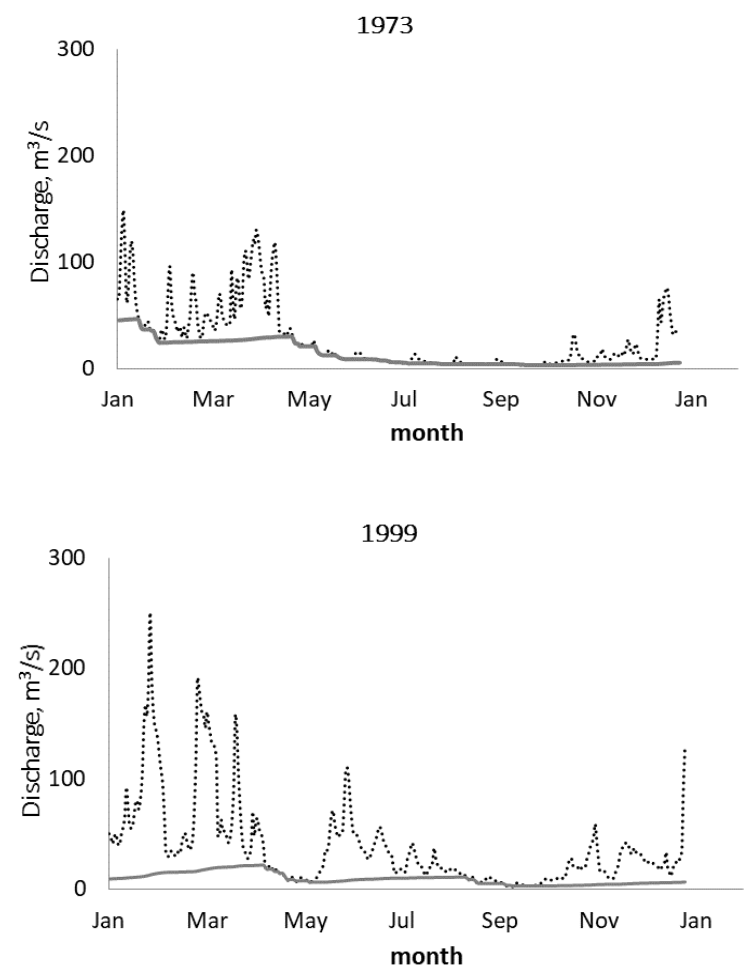

Figure 2. Baseflow separation for year 1973 and 1999

Where:

$\mathrm{q} b \quad$ : baseflow value $\left(\mathrm{m}^{3} / \mathrm{s}\right)$ 
The trend of yearly BFI is analysed to see whether the decrease in BFI values computed for years 1973 and 1999 is occasional or there is a trend in analysed data. Figure 3 shows the trend of yearly BFI and found that in fact there is a decrease trend over time with the highest and lowest values are 0.487 and 0.142 respectively. It is assumed if BFI values decrease then maximum discharges increase.

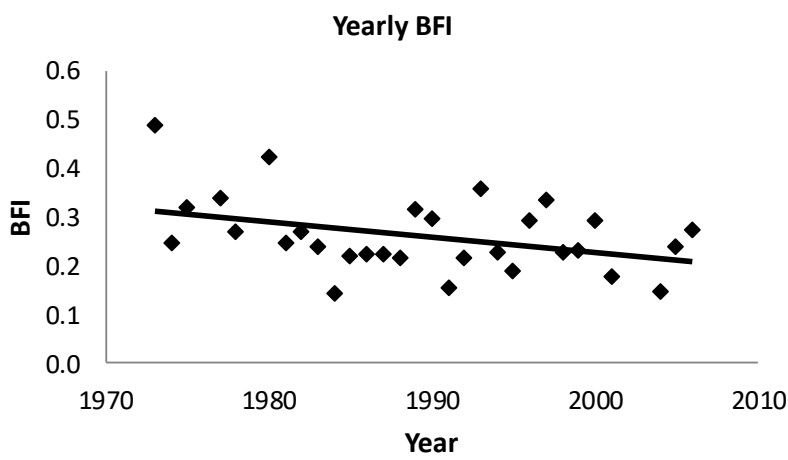

Figure 3. The trend of yearly BFI

Consequently, if high flows increase and low flows decrease, the average flow will decrease. This assumption is conformed with the result as presented in Figure 4 that observed discharges in this study show increase trend for maximum yearly flow and decreasing trend for average yearly flow, as presented on Fig. 4.
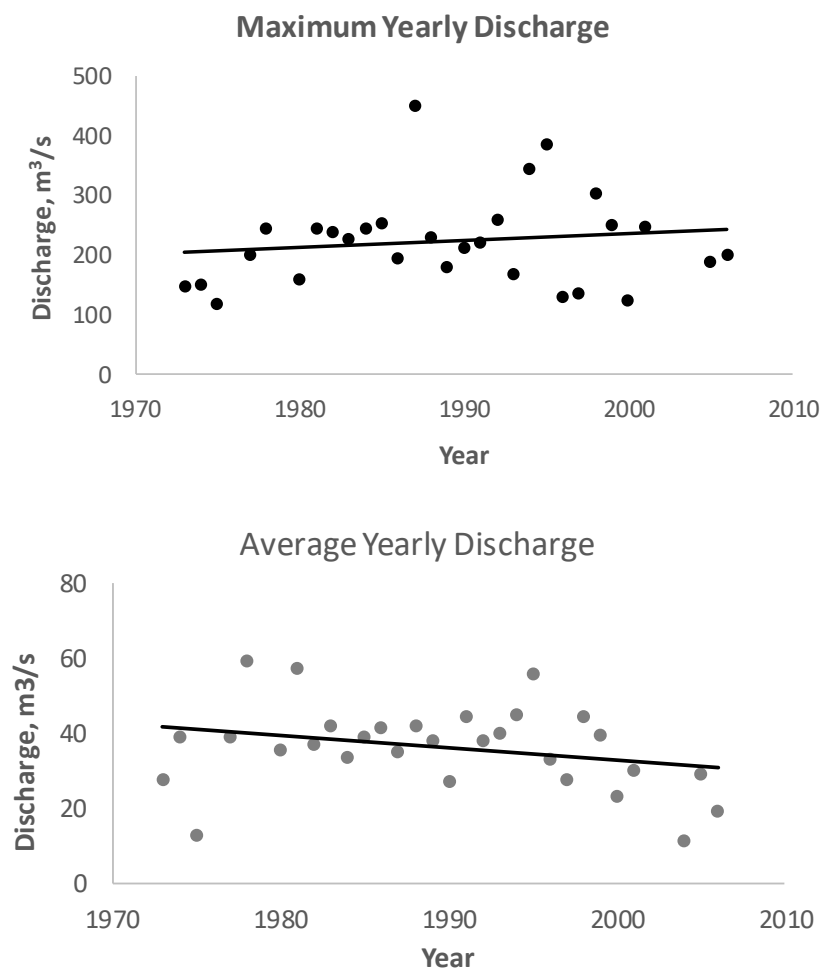

Figure 4. Maximum and Average of yearly discharges

According to [6] baseflow is a function of catchment properties such as topographic, geologic, soil and climatic properties. One of the catchment properties which can be evaluated is the land cover. Way Seputih catchment has been long exposed for forest clearing for wood production and there is a massive land use changes from dry land forest and agriculture for other purposes such as industrial and residential. To date land cover data that had been collected is only for year 2005 . However, such spatial land cover data is expected to give an illustration of the catchment. Figure 5 shows land cover map of Way Seputih catchment.

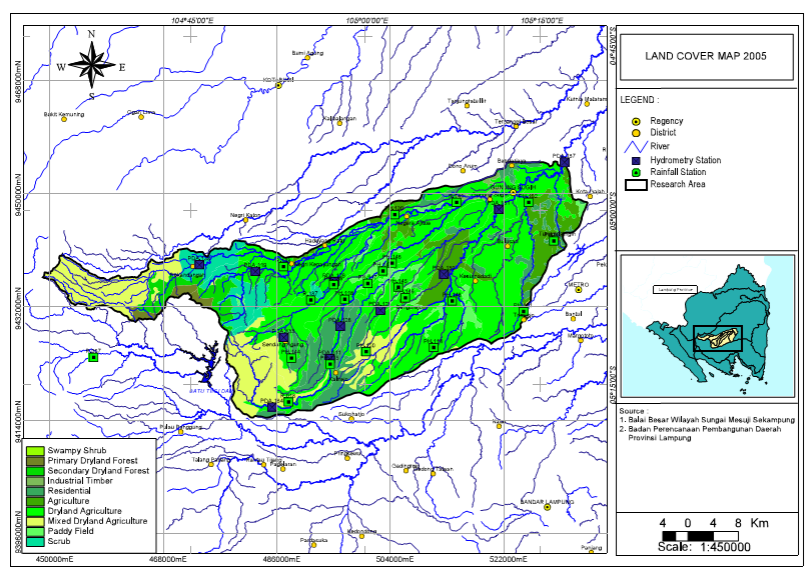

Figure 5. Land cover map of Way Seputih catchment

Table 1. Land Cover Type and Corresponding SCS Curve Number

\begin{tabular}{ccc}
\hline Land Cover Type & $\begin{array}{c}\text { Percentage } \\
\text { of Area (\%) }\end{array}$ & $\begin{array}{c}\text { SCS Curve } \\
\text { Number }\end{array}$ \\
\hline Wetland Shrub & 0.072 & 71 \\
Primary dryland forest & 1.097 & 70 \\
Secondary dryland forest & 3.047 & 73 \\
Industrial Timber & 0.377 & 57 \\
Residential & 10.093 & 90 \\
Agriculture & 8.673 & 81 \\
Dryland Agriculture & 51.992 & 82 \\
Mixed Dryland & 15.433 & 74 \\
Agriculture & & 78 \\
Paddy Field & 3.635 & 79 \\
Scrub & 5.580 & \\
\hline
\end{tabular}

To further show the impact of land cover on baseflow, it is used SCS curve number for the corresponding land cover as shown in Table 1. SCS curve number is a simple method used for determining the appropriate amount of runoff from a rainfall event in a particular area [7]. From the spatial analysis of land cover type, percentage of corresponding area and SCS curve number, it is found that SCS curve number composite for Way Seputih catchment is 80.665 . It 
means that around $20 \%$ of the rainfall which infiltrates into the soil and becomes baseflow.

Considering the result obtained from this study, it can be said that Way Seputih is in a critical catchment condition. An intensive action on soil and water conservation need to done by the authority together with society. The trend of yearly base flow index of Way Seputih catchment may change the type of the river from perennial river to intermittent river.

\section{Conclusions}

It can be concluded that analysis of Base Flow Index using Lyne-Holick RDF method has shown that BFI for Way Seputih river ranges from 0.142 to 0.487 with decreasing trend over time. This is confirmed by the result of average and maximum yearly discharges over time. The result also shows that with such low BFI values Way Seputih catchment can be considered in a critical cathcment condition. This too is confirmed by spatial land cover analysis of the catchment which found that 80 percent of the rainfall becomes surface runoff, and hence only around $20 \%$ of rainfall infiltrates into the soil and becomes baseflow. An urgent action needs to be done for the conservation of land and water.

\section{ACKNOWLEDGMENT}

This research is funded by Ministry of Research and Technology and Higher Education.

\section{REFERENCES}

[1] R. Brodie and S. Hostetler, "An Overview of Tools for Assessing Groundwater-Surface Water Connectivity". Canberra, Australia: Bureau of Rural Sciences Report, 2007.

[2] J. Zhang, Y. Zhang, J. Song and L. Cheng. (2017). Evaluating of relative merits of four baseflow separation methods in Eastern Australia. Journal of Hydrology. Vol. 549, pp. 252-263.

[3) D. D. Bosch, J. G. Arnold, P. G. Allen, K. Lim and Y. S. Park. (2017). Temporal variations in baseflow for the Little River experimental watershed in South Georgiam USA. Journal of Hydrology: Regional Studies. Vol. 10, pp. 110-121.

[4] X. S. Zhang, G. E. Amirthanathan, M. A. Bari, R. M. Laugesen, D. Shin, D. M. Kent, A. M. MacDonald, M. E. Turner and N. K. Tuteja. (2016). How streamflow has changes across Australia since the 1950s: evidence from the network of hydrologic reference stations. Hydrology and Earth System Sciences. Vol. 20, pp. 3947-3965.

[5] V. Lyne and M. Holick. (1979). Stochastic Time Variable Rainfall-Runoff Modelling. Institute Engineers Australia National Conference. Vol. 79 (10), pp. 89-83.

[6] S. Mwakalila, J. Feyen and G. Wyseure. (2002). The influence of physical catchment properties on baseflow in semi-arid environments. Journal of Arid Environment, 52, pp. 245-258.

[7] T. Nayak, M. K. Verma and B. S. Hema. (2012). SCS curve number method in Narmada basin. International Journal of Geomatics and Geosciences. Vol. 3(1), pp. 219-228. 